Original Article

\title{
Mortality of the cotton boll weevil in drip and sprinkler irrigated cotton crops
}

\author{
Mortalidade do bicudo-do-algodoeiro em lavouras de algodão irrigadas por \\ gotejamento e aspersão
}

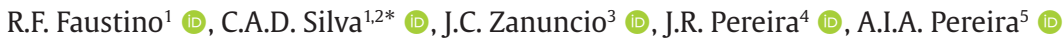 \\ ${ }^{1}$ Universidade Estadual da Paraíba - UEPB, Programa de Pós-graduação em Ciências Agrárias, Campina Grande, PB, Brasil \\ 2Empresa Brasileira de Pesquisa Agropecuária, Laboratório de Entomologia, Centro Nacional de Pesquisa de Algodão, Campina Grande, PB, \\ Brasil \\ ${ }^{3}$ Universidade Federal de Viçosa - UFV, Departamento de Entomologia/BIOAGRO, Viçosa, MG, Brasil \\ ${ }^{4}$ Empresa Brasileira de Pesquisa Agropecuária, Centro Nacional de Pesquisa de Algodão, Departamento de Irrigação, Campina Grande, PB, Brasil \\ ${ }^{5}$ Instituto Federal Goiano - IFG, Campus Urutaí, Urutaí, GO, Brasil
}

\begin{abstract}
The cotton boll weevil, Anthonomus grandis grandis Boheman (Coleoptera: Curculionidae), is a key cotton crop pest in Brazil. Adverse climatic factors, such as high temperatures and low soil moisture, dehydrate oviposited cotton squares (bud flowers) on the ground and cause high mortality of its offspring within these plant structures. The objective of this research was to evaluate the mortality of the cotton boll weevil in drip and sprinkler irrigated cotton crops. The experimental was in included randomized blocks with two treatments: drip (T1) and sprinkler (T2, control) irrigated cotton crops with sixteen replications. Each parcel had one emergence cage, installed between two cotton rows per irrigation system, with 37 cotton squares with opened oviposition punctures and yellowish bracts, to capture adult cotton boll weevils. The average number of boll weevils that emerged from the cotton squares and the causes of mortality at different development stages were determined per treatment. Third-generation life tables of the boll weevil were prepared using the natural mortality data in drip and sprinkler irrigation treatments and plus actual, apparent and indispensable mortality rates and the lethality of each mortality cause. We conclude that the application of water directly to the root zone of the plants in a targeted manner, using the drip irrigation system, can cause high mortality of the cotton boll weevil immature stages inside cotton squares fallen on the ground. This is because the cotton squares fallen on the drier and hotter soil between the rows of drip-irrigated cotton dehydrates causing the boll weevils to die. This is important because it can reduce its population density of the pest and, consequently, the number of applications of chemical insecticides for its control. Thus, contributing to increase the viability of cotton production, mainly in areas of the Brazilian semiarid region where the cotton is cultivated in organic system.
\end{abstract}

Keywords: Anthonomus grandis grandis, Gossypium hirsutum, insect desiccation, irrigation system.

\begin{abstract}
Resumo
O bicudo-do-algodoeiro, Anthonomus grandis grandis Boheman (Coleoptera: Curculionidae), é uma praga-chave da cultura do algodão no Brasil. Fatores climáticos adversos, como altas temperaturas e baixa umidade do solo, desidratam os botões florais de algodão ovipositados caídos ao solo e causam alta mortalidade de seus descendentes dentro dessas estruturas vegetais.O objetivo desta pesquisa foi avaliar a mortalidade do bicudo-do-algodoeiro em lavouras de algodão irrigadas por gotejamento e aspersão. O delineamento experimental foi em blocos casualizados com dois tratamentos: cultivo de algodão irrigado por gotejamento (T1) e aspersão (T2, testemunha) com dezesseis repetições. Cada parcela possuía uma gaiola de emergência, instalada entre duas fileiras de algodão por sistema de irrigação, com 37 botões florais de algodão com orifícios de oviposição, brácteas abertas e amarelecidas, para captura do bicudo adulto. O número médio de bicudos que emergiu dos botões florais de algodão e as causas de mortalidade, em diferentes estágios de desenvolvimento, foram determinados por tratamento. As tabelas de vida de terceira geração do bicudo-do-algodoeiro foram preparadas usando os dados de mortalidade natural em tratamentos de irrigação por gotejamento e aspersão e as taxas de mortalidade reais, aparentes e indispensáveis e a letalidade de cada causa de mortalidade. Concluímos que a aplicação de água diretamente na zona radicular das plantas de forma direcionada, utilizando o sistema de irrigação por gotejamento, pode causar altas mortalidade dos estágios imaturos do bicudo-do-algodoeiro nos botões florais de algodão caídos no solo. Isso ocorre porque os botões florais de algodão caídos no solo mais seco e mais quente entre as fileiras do algodão irrigado por gotejamento
\end{abstract}

*e-mail: carlos.domingues-silva@embrapa.br

Received: January 30, 2021 - Accepted: May 13, 2021

This is an Open Access article distributed under the terms of the Creative Commons Attribution License, which permits unrestricted use, distribution, and reproduction in any medium, provided the original work is properly cited. 
desidratam, causando a morte dos bicudos. Isso é importante por poder reduzir a densidade populacional desse inseto e, consequentemente, o número de aplicações de inseticidas químicos para seu controle. Assim, contribuindo para aumentar a viabilidade da produção de algodão, principalmente em áreas do semiárido brasileiro em sistema orgânico.

Palavras-chave: Anthonomus grandis grandis, Gossypium hirsutum, dessecação de inseto, sistema de irrigação.

\section{Introduction}

Brazil is one of the largest cotton producers in the world, with an estimated cultivated area of 1.1 million hectares (IBGE, 2020) mainly in the Cerrado Biome with rainfed conditions (Ferreira et al., 2020). However, this culture is expanding with areas irrigated, mainly small properties in the semi-arid region of the Northeast Brazil (Bezerra et al., 2015). The irrigation is essential in this region due to water deficiency during the crop cycle caused by low and poor distributed rainfall rates (Zonta et al., 2015). The Northeast irrigated areas accounts for, approximately $22 \%$ of those in Brazil (Paulino et al., 2011).

Water delivery and the environmental conditions created can affect insect pests in production units (Silva et al., 2019). Drip irrigation, for example, keeps the soil dry and warm between the rows of cultivated plants, which can harm insects that need environments with mild temperatures and high humidity to develop and reproduce (Amini et al., 2012; Rendon and Walton, 2019). Drip-irrigated coffee plants have fewer leaf miners than non-irrigated ones (Assis et al., 2012). The low water availability and low relative humidity increased the death rates of Drosophila suzukii (Matsumura) (Diptera: Drosophilidae) and its egg laying and increased the $P$. vindemmiae feeding on pupae of this pest. In addition, drip irrigation can turn soil humidity conditions unfavorable to soil pathogens (Panth et al., 2020) and can be used to apply fertilizers and pesticides, including biopesticides (Ghidiu et al., 2012; Jiang et al., 2019, 2020). However, the high volumes of drip irrigation in vines can increase lateseason leafhopper populations (Daane and Williams, 2003).

Sprinkler irrigation, in turn, can remove pests such as aphids, caterpillars, mites and thrips from plants (Medeiros et al., 2011; Runia et al., 2014), but it also increases the risk of leaf diseases favoring phytopathogen spore germination (Lopes et al., 2006).

Over 260 insect species feed on cotton plants throughout their phenological cycle (Allen et al., 2018) with $10 \%$ being pests (Ribeiro et al., 2015; Silva et al., 2018). The cotton boll weevil, Anthonomus grandis grandis Boheman (Coleoptera: Curculionidae), is a key pest, reducing cotton crop productivity by up to $60 \%$ (Silva and Ramalho, 2013).

The cotton boll weevil (CBW) causes losses, such as high abscission of cotton squares (bud flowers) and abnormal opening of its capsules in all Brazilian cotton-producing regions due to its eating habits and oviposition in the plant reproductive structures (squares and small bolls) (Silva et al., 2013, 2017). Cotton squares abscission occurs especially in those formed between 40 and 60 days old, depending on the cotton variety (Ribeiro et al., 2010; Pimenta et al., 2016).

Boll weevil adults are mainly controlled with frequent applications of chemical insecticides, which increase the production costs of cotton crops (Bélot et al., 2016). In Brazil, $10 \%$ of the production costs per harvest are necessary to control the boll weevil (CEPEA, 2019) because its immature stages develop within the cotton reproductive structures (squares and small bolls) reducing the effect of the insecticides (Silva and Silva, 2015; Barros et al., 2019). The dehydration of the cotton squares on the soil by adverse climatic factors, such as high temperatures and low soil moisture, increases mortality of boll weevil larvae and pupae inside these plant structures (Ramalho et al., 1993; Ramalho and Wanderley, 1996).

The hypothesize of this study is that the drip irrigation can keep the soil between cotton rows drier and with high temperature, which will increase the mortality of the immature stages of the cotton boll weevil by its desiccation inside cotton squares. Natural mortality studies are important to develop management strategies for insect pests including the boll weevil populations, and to understand its mortality causes (Ramalho et al., 1993; Ramalho and Wanderley, 1996). The construction of ecological life tables allows assessing qualitative and quantitative mortality factors (Pereira et al., 2007). The objective of this research was to evaluate the key mortality factors of the CBW in drip and sprinkler irrigation systems, using ecological life tables.

\section{Material and Methods}

\subsection{Field sites and plant material}

The study was carried out at the Embrapa Cotton Experimental Station in Barbalha, state of Ceará, Brazil ( $7^{\circ} 18^{\prime} 18^{\prime \prime}$ S latitude and $39^{\circ} 18^{\prime} 7^{\prime \prime} \mathrm{W}$ longitude) and at the Embrapa Algodão Entomology Laboratory in Campina Grande, state of Paraíba, Brazil ( $7^{\circ} 13^{\prime}$ '50" S latitude and $35^{\circ} 52$ ' $52^{\prime \prime}$ W longitude) between January and December, 2019.

The physiological conditions of the cotton plants and the weather of the cultivation area where the damaged cotton squares by CBW were collected were assumed not influencing the results. The abscission of punctured cotton squares by boll weevil oviposition depends on the enzyme pectinase produced by its second and third instar larvae (King, 1973). The cotton squares were obtained from cotton plants (genotype BRS 286), grown in a $480 \mathrm{~m}^{2}$ experimental area (12 x 40 m) at Embrapa Algodão in Campina Grande in the first half of 2019. These plants were grown spaced $0.90 \times 0.10 \mathrm{~m}$ leaving one per hole after thinning. Seventy days after germination, 1,184 cotton squares with boll weevil oviposition punctures plus yellow and open bracts under the plant canopies of and between the rows, easily detached from the plant, were randomly collected (Ramalho et al., 1993). A total of 37 cotton squares were placed per paper 
bag, labeled and stored in a polystyrene box for 16 hours, prior to initiating the experiment.

\subsection{Determination of the causes of the cotton boll weevil mortality}

CBW survival per development stage was determined in an experimental field of the Embrapa Cotton in Barbalha using the cotton cultivar BRS 286, from July to September, 2019 with low precipitation $(\sim 7 \mathrm{~mm})$ and average daily temperatures of $\sim 25{ }^{\circ} \mathrm{C}$ (INMET, 2009). Because the climatic conditions registered during the execution of the experiment were adjusted to the average of the last 30 years climatological data observed in the municipality of Barbalha, we assumed that it is unnecessary to repeat the bioassay for another year.

The experimental area was $560 \mathrm{~m}^{2}(10 \times 56 \mathrm{~m})$ and the plants spaced $0.90 \times 0.10 \mathrm{~m}$, leaving one per role after thinning. The experiment started with the presence of cotton squares on the plants, 65 days after their germination.

The experimental design was in a randomized block with two treatments: drip (T1) and sprinkler (T2, control) irrigated cotton crops with 16 replications. The experimental unit consisted of a cylindrical emergence cage (the boll weevil adults alive emerged from the cotton squares) with a frame made with PVC pipe $(20 \mathrm{~cm}$ high by $20 \mathrm{~cm}$ in diameter) surrounded by white nylon plastic screen, $0.5 \mathrm{~mm}$ mesh and closed at the top by transparent plastic film. The cages were installed between two of five $1.5 \mathrm{~m}$ long cotton rows. Thirty-seven cotton squares with an average size of $1.45 \mathrm{~mm}$ were collected and placed on the soil surface per cage. The total was 1,184 cotton squares damaged by the weevils. The soil between the cotton rows was kept clear during the experiment.

The irrigation regimes were based on the water storage capacity of the soil and the water consumption by the cotton plants (Dağdelen et al., 2009). Irrigation was carried out whenever the soil moisture was around $50 \%$ in the root zone at $0.60 \mathrm{~m}$ depth in both irrigation systems. Water consumption was estimated as a function of the reference evapotranspiration (IETo), calculated from the daily data obtained at the INMET weather station in Barbalha, by the cultivation coefficient (Kc) using the Penman-Monteith method and determined experimentally for the cotton culture (Bezerra et al., 2012).

In the sprinkler irrigation system, the water was uniformly applied before planting, with four pluviometers spaced $3 \mathrm{~m} \times 3 \mathrm{~m}$ in the area with the micro-sprinklers (Andrade et al., 2017). Sprinkler irrigation was performed with 75\% efficiency, using micro-sprinklers (AraujoRevolution, Model HI-25), spaced $6 \mathrm{~m}$ x 6m, with two lateral rows of $22.9 \mathrm{~m}$ long and a service pressure of 13.36 mca with an average precipitation of $12.06 \mathrm{~mm} \mathrm{~h}^{-1}$. Drip irrigation consisted of two subunits, each with five lateral rows $12.9 \mathrm{~m}$ long, spaced $0.90 \mathrm{~m}$ (one lateral line per cotton row) with an outlet every $0.30 \mathrm{~m}$ and $95 \%$ efficiency with pressure service at the entrance of the lateral row of $21.09 \mathrm{mca}$ and average flow of $0.756 \mathrm{l} \mathrm{h}^{-1}$.

Soil temperature and humidity, in 16 and eight sampling points, respectively, per irrigation system were determined at 9, 11, 13 and 15 hours, of each day, for 10 days, corresponding to the period between the installation of the cages and the emergence of the cotton boll weevils. The correlation between the numbers of dead CBW and irrigation systems was calculated with the averages of these parameters. The sampling points were equidistant from each other, between two cotton rows, in the same line and the cages.

The soil temperature was determined with a digital thermometer (4 in 1 Soil Survey Instrument) and the relative humidity with an analog soil hygrometer $(\mathrm{pH}$ meter and soil moisture, Model PH-3000), daily, until the total emergence of the CBW adults from the cotton squares. These adults were removed from the cages and the cotton squares collected, packed in labeled paper bags and taken to the Laboratory for dissection and to determine the natural mortality causes (desiccation, unviable eggs, disease, parasitism and predation).

The dissection was performed by removing the calyx and petals of cotton squares with the aid of a stylet under stereomicroscope.

Unviable eggs due to desiccation were determined by subtracting the $13.5 \%$ unviable ones due to cell proliferation and/or formation of gelatinous substance in the cotton squares (Hinds, 1906) from the percentage of unviable eggs due to all mortality agents.

The instar of dead boll weevil larvae within the cotton squares was determined by its head capsule width, measured with a digital caliper. The widths of cephalic capsules of the first, second and third instar larvae of A. grandis grandis are $0.41,0.62$ and $0.99 \mathrm{~mm}$, respectively (Parrott et al., 1970).

\subsection{Cotton boll weevil life table}

Two ecological life tables, from the third generations, were constructed with data on the natural mortality of the boll weevil within the cotton squares in drip and sprinkler irrigation treatments (Ramalho and Silva, 1993). These tables allow determining and quantifying the lethality of each one for the real, apparent and indispensable mortality of the boll weevil. The first column (X) represents the weevil developmental stage: egg, larva, pupa, adult pre-emerged (PA) (dead inside the cotton squares) and emerged adult (alive from the cotton squares) (EA). The second column (Lx) is the number of live insects in stage X.

The elaboration of the life tables started with the insect eggs in 585 and 588 cotton squares with oviposition punctures by the CBW. The value of $\mathrm{Lx}$, for the $\mathrm{X}$ development stage, was obtained by subtracting the number of dead insects from those alive in the previous stage, until the total emerged boll weevils was obtained.

Mortality $\mathrm{C}$ is the factor responsible for the insect death in the stage $\mathrm{X}$. This factors are unviable egg, desiccation, parasitism and predation. Unviable eggs include all embryo mortality causes (infertility, disease, desiccation, the proliferation of cellular tissues of cotton squares and/or formation of gelatinous substances responsible for crushing the egg inside these plant structures) (Hinds, 1906; Ramalho et al., 1993). 
Dxc is the number of insects dead per stage $X$ due to cause $\mathrm{C}$. The percentage of actual mortality (\% Dxc) is the number of dead individuals per stage calculated as a function of the number of insects at the beginning of each stage with the equation: \% Dxc= Dxc/L(egg) + Dxc/ L(egg) $x 100$, where Dxc is the number of dead insects in stage $\mathrm{X}$ and $\mathrm{L}$ (egg) that of viable eggs at the beginning of the generation. The equation calculates the percentage of actual mortality, per generation, from egg to pre-emerged boll weevil adult.

The percentage of apparent mortality (100Qxc) is the number of dead insects per stage. It is calculated by the function of the number of live insects at the beginning of each of that of the boll weevil, with the equation: $100 \mathrm{Qxc}=\mathrm{Dxc} / \mathrm{Lx}(\mathrm{Dxc} / \mathrm{Lx}) \times 100$, where Dxc is the number of dead insects in the stage $\mathrm{X}$ due to the action of $\mathrm{C}$, and Lx the number of live insects in stage $X$.

The mortality/survival ratio (MSxc) was estimated with the equation MSxc= Dxc/Lx (Dxc/Lx). The indispensable mortality (MIxc), for the development stage X and mortality cause $\mathrm{C}$, was obtained by multiplying the number of adults emerged by the percentage of mortality (MSxc).

Lxc values were obtained by subtracting Dx (c-1) from Lx (c-1). Lethality (Kxc) (Varley and Gradwell, 1968), at the different development stages of the boll weevil, was calculated with the decimal logarithm $(\log 10)$ of Lxc $(\log 10 \mathrm{Lxc})$ with the equation: $\mathrm{Kxc}=\log 10[\mathrm{Lx}(\mathrm{c}-1)]-\log 10[\mathrm{Lx}(\mathrm{c})]$.

\subsection{Data analysis}

The number of adult CBW emerged from the cotton squares and the mortality data, at different development stages of this insect per treatment, were subjected to the Liliefors normality test and transformed into $\sqrt{x}+0.5$ when necessary, to meet the pre-requirements for the analysis of variance (ANOVA). The data were then subjected to analysis of variance and the means compared by Fisher's test (LSD) at 5\% probability using the System of Statistical and Genetic Analysis (SAEG) of the Federal University of Viçosa.

\section{Results and Discussion}

The soil texture in the experimental area is sandy $(93.8 \%$ sand, $2.5 \%$ silt and $3.7 \%$ clay) with a field capacity of $0.1 \mathrm{~atm}$, an overall density of $1.5 \mathrm{~kg} . \mathrm{cm}^{-3}$, particles of $2.7 \mathrm{~kg} . \mathrm{cm}^{-3}$ and total porosity of $44.8 \%$. The uniformity coefficient, before irrigation, was $94.3 \%$, close to the maximum desirable (Prado, 2016), characterizing a good water distribution in the irrigation systems. A total of $527.0 \mathrm{~mm}$ of water was supplied during the phenological cycle of the cotton culture by the sprinkler and drip irrigation systems, twice a week according to the capacity of soil water retention and the crop evapotranspiration.

\subsection{Cotton boll weevil mortality causes}

The number of adult CBW emerged from the cotton squares was higher in the sprinkler $(0.35 \pm 0.11)$ and lower $(0.00 \pm 0.00)$ in the drip treatment per emergency cage $\left(\mathrm{F}_{1.15}=9,00 ; \mathrm{P}<0.01\right)$. This is probably due to the higher mortality of the immature boll weevils in the drip irrigation system due to the higher temperature $\left(41^{\circ} \mathrm{C}\right)\left(\mathrm{F}_{1 \cdot 15}=69.73\right.$; $\mathrm{P}<0.01)$ and lower relative humidity of the soil (9.7\%) $\left(\mathrm{F}_{1.15}=29,97 ; \mathrm{P}<0.01\right)$ compared to temperature $\left(37^{\circ} \mathrm{C}\right)$ and relative humidity (16\%) of the soil in the sprinkler irrigation system (Figure 1). This was observed for the immature stages of the boll weevil, in the cotton squares with oviposition punctures submitted to temperatures of $35^{\circ} \mathrm{C}$ and $40^{\circ} \mathrm{C}$ and relative humidity of 89.1 and $96.2 \%$ (Greenberg et al., 2005). The water and nutrient losses in insects increase at temperatures above $50^{\circ} \mathrm{C}$ causing depletion, decreasing motility, tissue damage and rapid death (Harrison et al., 2012). Drip irrigation keeps the cotton rows clear in semi-arid areas what can reduce boll weevil populations by dehydrating the cotton squares with oviposition punctures fallen to the ground (dry and hot) (Silva et al., 2013).The number of adult boll weevils in the sprinkler treatment was relatively low, but it cannot be neglected, considering the high biotic potential of this pest (Pires et al., 2017).

The number of unviable eggs $\left(\mathrm{F}_{1.15}=4.99 ; \mathrm{P}=0.04\right)$ and post-embryonic immature stages of the boll weevil dead due to desiccation $\left(\mathrm{F}_{1.15}=4.34 ; \mathrm{P}=0.05\right)$ inside cotton squares with oviposition punctures on the soil surface differed between the irrigation systems (Figure 2A) with interaction between them and the causes of unviable eggs $\left(F_{1.45}=7.42 ; \mathrm{P}<0.01\right)$ (Figure 3 ). However, CBW killed by parasitism $\left(\mathrm{F}_{1.15}=1.00 ; \mathrm{P}=0.33\right)$ or predation $\left(\mathrm{F}_{1.15}=0.13 ; \mathrm{P}>0.05\right)$ was similar in drip or spray irrigated cotton. The number of unviable eggs due to desiccation was higher in the drip irrigation system $\left(\mathrm{F}_{1.45}=7.33\right.$; $\mathrm{P}<0.01$ ), similar to that observed for cell proliferation and/or formation of gelatinous substance in dripping and sprinkling $\left(\mathrm{F}_{1.45}=5.46 ; \mathrm{P}=0.02\right)$ systems, respectively. The number of unviable eggs due to cell proliferation and/or gelatinous substance formation was similar in both irrigation systems. Egg unviability due to the boll weevil infertility or disease is, normally, not significant, contrary to this due to desiccation or cell proliferation and/or gelatinous substance formation (Coelho et al.,

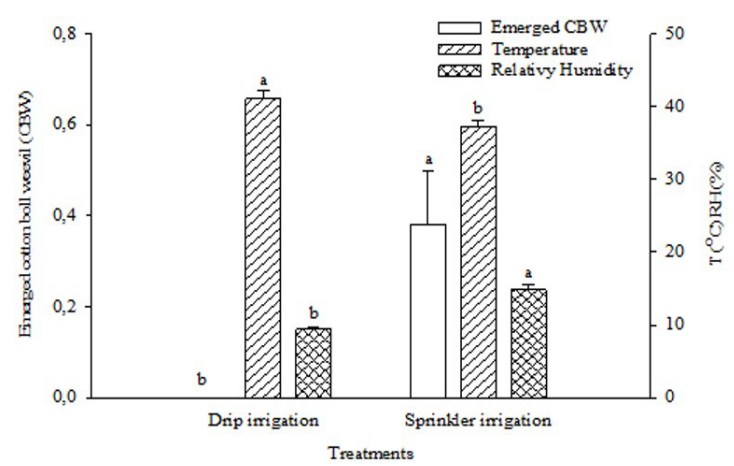

Figure 1. The number of cotton boll weevils (CBW) emerged per cotton square cage on the soil surface, and average daily temperature and relative humidity of the soil in drip and sprinkler irrigated cotton. Means followed by the same letter per column between treatments do not differ by Fisher's LSD test at $5 \%$. Means of cotton boll weevil emerged from cotton squares per cage transformed into $\sqrt{x}+0.5$ for statistical analysis. Original means are shown. 
2016). Cell proliferation in the cotton square is quite fast, with new cells formed crushing and destroying the egg deposited by the boll weevil female inside the cotton square (Ramalho et al., 1993; Hilker and Meiners, 2002).
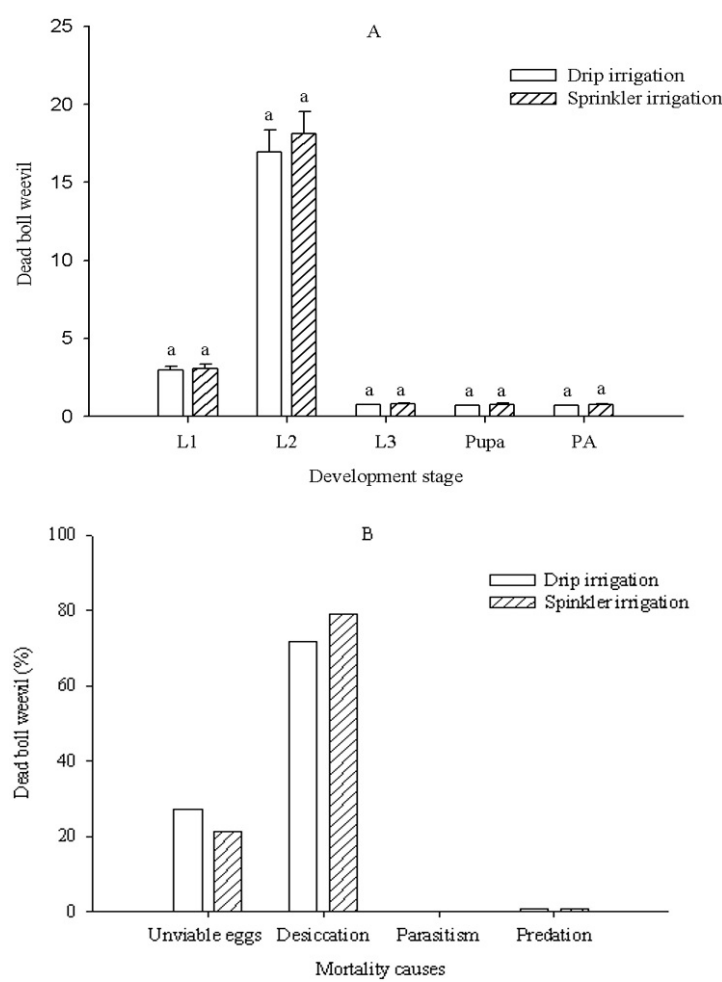

Figure 2. The number (A) and percentage (B) of dead cotton boll weevils ( $\mathrm{CBW}$ ) by different causes inside the cotton squares on the soil surface in relation to the total of dead CBW within these plant structures, in drip and sprinkler irrigated cotton. Means followed by the same letter in the columns, due to mortality, do not differ by Fisher's LSD test at $5 \%$ probability.

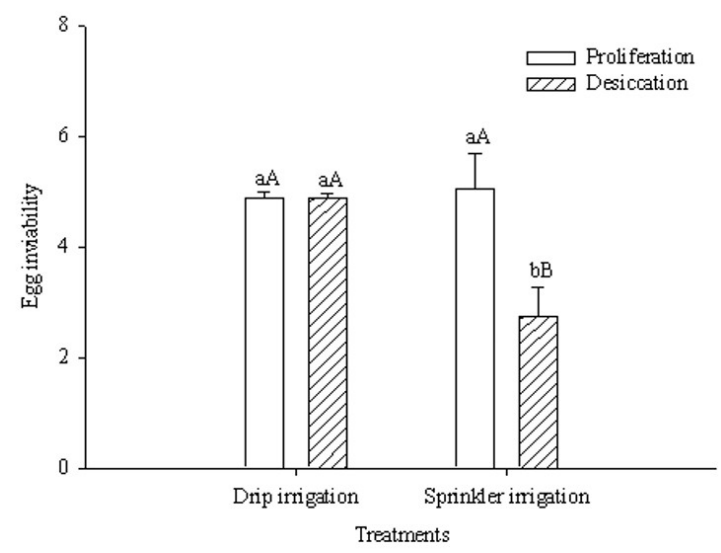

Figure 3. The number of unviable eggs due to cell proliferation and/or gelatinous substance formation and desiccation inside cotton squares on the soil in drip and sprinkler irrigated cotton. Means followed by the same lower case letter by type of unviable and upper case between treatments do not differ by the Tukey test at $5 \%$ probability.
The gelatinous substance is sticky and it is a product from the physiological reaction of the cotton squares to a foreign body, which can kill the eggs or prevent the A. grandis grandis larvae emergence (Hilker and Meiners, 2002). The term egg unviability, in this research, refers to agents of egg mortality besides unviable eggs due to desiccation. This condition was pre-established, because it is difficult to finding very small size eggs inside the completely dry cotton square and to determine is specific death cause. The numbers of unviable eggs (9.94 \pm 0.63 ) and those killed by desiccation $(5.05 \pm 0.63)$ was higher in the drip than that of unviable ( $7.63 \pm 0.71$ individuals) or dried ( $2.73 \pm 0.53$ individuals) eggs in the sprinkling water system (Figures 2 and 3). On the other hand, the number of dead boll weevils killed by desiccation in the post-embryonic immature stages was higher in the sprinkling (28.63 \pm 0.66 individuals) than in dripping ( $26.25 \pm 0.74$ individuals) systems. This is probably due to the higher temperature and lower relative humidity of the soil in the dripping system, which accelerates the egg drying process and mortality at the initial development stages of the boll weevil inside the cotton squares in this treatment.

Desiccation was the major cause of natural CBW mortality in both treatments causing 99\% mortality due to unviable eggs and death in the post-embryonic immature stages of this insect (Figure 2B). The parasitism and predation were low in the treatments, 27\%, 72\%, $0.2 \%$ and $0.9 \%$ in the drip (Figure 2B) and 21\%, 78.5\%,0\% and $0.5 \%$ in the sprinkler systems, respectively. Mortality due to desiccation of first $\left(\mathrm{F}_{1.15}=0.16 ; \mathrm{P}>0.05\right)$, second $\left(\mathrm{F}_{1.15}=0.98 ; \mathrm{P}>0.05\right)$ and third $\left(\mathrm{F}_{1.15}=2.06 ; \mathrm{P}=0.17\right)$ instar larvae, pupae $\left(\mathrm{F}_{1.15}=1.0 ; \mathrm{P}=0.33\right)$ and pre-emerged CBW adult $\left(\mathrm{F}_{1.15}=1.0 ; \mathrm{P}=0.33\right)$ inside the cotton squares on the soil was similar for drip and sprinkler irrigated cotton crops (Figure 4A), $2.97 \pm 0.25,16.94 \pm 1.42,0.74 \pm 0.03$, $0,71 \pm 0.00$ and $0.71 \pm 0.00$ and $3.07 \pm 0.26 ; 18.13 \pm 1.41$, $0.79 \pm 0.06,0.76 \pm 0.07$ and $0.76 \pm 0.05$, respectively. Mortality of the CBW due to desiccation was higher in both irrigation systems with $25.6 \%, 46.8 \%, 0.2 \%, 0.0 \%$ and $0.0 \%$ with drip and $27.6 \%, 50.0 \%, 0.5 \%, 0.5 \%$ and $0.4 \%$ with sprinkler irrigated cotton crops (Figure 4B) for the first, second and third instar larvae, pupae, and pre-emerged adults, respectively. This was greater than the $8.9 \%, 25.0 \%$ and $18.0 \%$ mortality of first, second and third instar larvae of the boll weevil and lower than the $15 \%$ and $0.0 \%$ of pupae and pre-emerged adults of this insect at $35^{\circ} \mathrm{C}$ (Greenberg et al., 2005).

The high mortality of larvae, pupae and pre-emerged adults of CBW by desiccation is the main cause of natural mortality of this insect pest followed by parasitism and predation (Ramalho and Wanderley, 1996; Ramalho et al., 2007; Santos et al., 2013). Arthropod mortality due to desiccation generally results from water loss because these organisms have a high surface area to body volume ratio, storing proportionally low amounts of fat and having high metabolic rate (Gibbs et al., 2003; Bujan et al., 2016). The tolerance threshold for water losses varies between insect species, even between those of the same gender, geographic location and frequency and duration of exposure to drought (Baudier et al., 2015; Kaspari et al., 2015). 

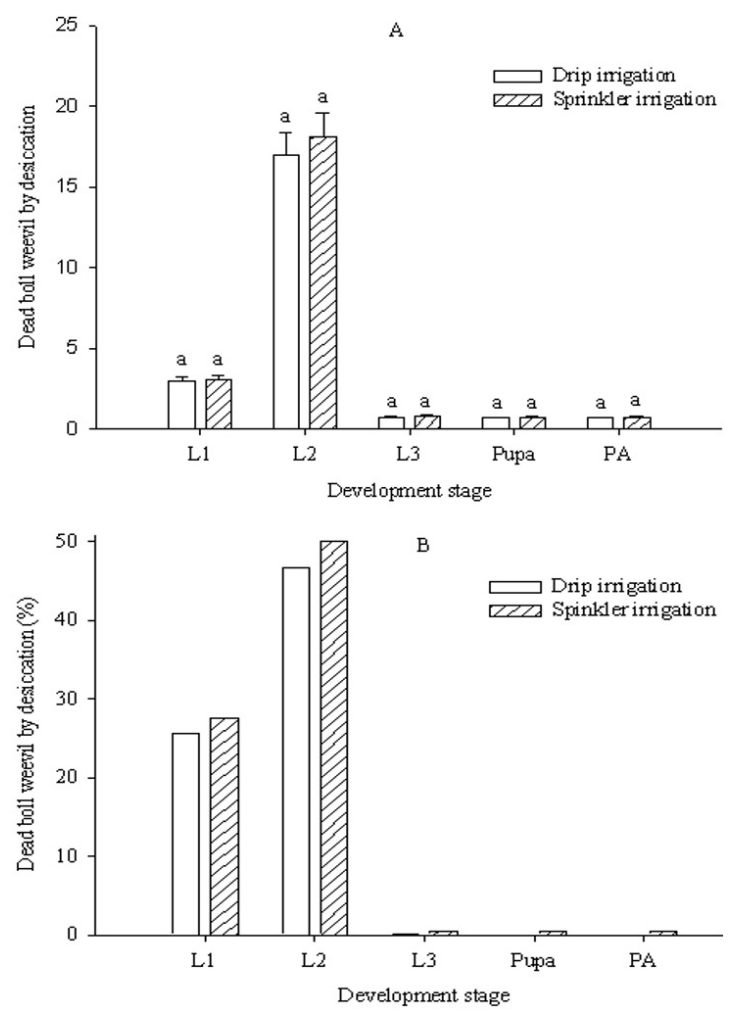

Figure 4. The number (A) and percentage (B) of dead boll weevils by desiccation in immature post-embryonic stages $(\mathrm{L} 1=$ first stage larva, L2 = second stage larva, L3 = third stage larva, pupa and PA = pre-emergent adult) inside cotton squares on the soil in relation to the total of dead boll weevils within these plant structures in drip and sprinkler irrigated cotton. Means followed by the same letter in the columns, due to mortality, do not differ by Fisher's LSD test at $5 \%$ probability. Means transformed into $\sqrt{x}+0.5$ for statistical analysis.

The lowest mortality of the boll weevil mortality by natural causes in cotton plants irrigated by drip and sprinkler may be due to the physical barrier exerted by the cages preventing and/or hindering the access of the parasitoids Bracon vulgaris Ashmead (Hymenoptera: Braconidae) and Catolaccus grandis (Burks) (Hymenoptera: Pteromalidae) to cotton squares and reducing the number of predatory ants, which avoid cotton squares with immature boll weevils dead from desiccation (Hinds, 1907). The cotton squares with irregular holes and ripped edges, indicate predation by ants, but the ant genus responsible for the weevil predation was not determined (Ramalho et al., 1993). Ants preying larvae, pupae and pre-emerged adult of the boll weevils are mainly of the genera Solenopsis group germinata sp., Pheidole sp., and Crematogaster sp. (Ramalho and Silva, 1993; Ramalho et al., 1993).

\subsection{Cotton boll weevil life table}

The life tables, of CBW three generations, with natural mortality data showed the emergence of live adults of this insect in six and zero of the 585 and 588 cotton squares with oviposition punctures in the sprinkler and drip irrigation systems, respectively (Table 1 ). The higher emergence of the boll weevil in this last treatment is related to light, temperature, and humidity intensity (Ramalho et al., 1993).

The real (\% Dxc) and apparent (100Qxc) mortality of the CBW, within cotton squares on the soil surface, was 100 and $99 \%$ in the areas with irrigation by drip and sprinkler systems, respectively (Table 1 ), mainly due to larvae desiccation, followed by egg desiccation. This is probably due to the greater vulnerability of these immature boll weevil stages as reported for desiccation, an important physical agent with deleterious effect of high temperatures and low soil humidity on this insect (Ramalho and Wanderley, 1996; Greenberg et al., 2004; Showler, 2007).

The indispensable mortality (Mlxc) of the immature boll weevil stages was completely estimated only in the cotton crop irrigated by sprinkling, because all immature stages of this insect died in the drip system. The lack of knowledge of all the mortality causes per boll weevil development stage in the drip system makes it impossible to estimate the relative importance of these factors in the subsequent population density of this insect (Southwood and Henderson, 2000; Naranjo and Ellsworth, 2017).

The lethality $(\mathrm{Kxc})$ of desiccation was the greatest mortality per development stage of the boll weevil (Table 1 ). The reduction in the lethality of parasitism and predation of the boll weevil larvae may be related to the difficulty of these natural enemies to access the immature boll weevil stages and/or the lower preference of predators for these immature stages killed by desiccation (Hinds, 1907; Ramalho et al., 1993).

The absence of CBW, emerging from the cotton squares on the soil surface and between the rows of cotton plants in the drip system, indicates that this irrigation system can reduce their populations by desiccation because the water is applied directly to the root zone of plants. This reduces soil humidity and increases the temperatures, mainly between the cotton rows where the majority of cotton squares punctured for oviposition by the boll weevil fall (Silva et al., 2013; 2017).

The drip irrigation system is more advantageous than the sprinkler irrigation because it maximize yields from cotton cultivation on small rural properties in the semiarid region (Bhatti and Patel, 2015; Zulfiqar et al., 2017), and can reduce or prevent the emergence of the CBW adults from infested cotton squares fallen on the ground. This reduction in the emergence of cotton boll weevils occurs because the cotton squares dehydrate on the drier and warmer soil between the rows of cotton drip-irrigated causing the death of immature stages of this pest by desiccation. These are interesting findings because the environment control through irrigation has never been reported as an important cultural practice to cause high mortality in cotton boll weevil inside cotton squares fallen on the ground. Therefore, this is important because it can reduce its population density and, consequently, the number of applications of chemical insecticides to control this pest. Thus contributing to increase the viability of cotton production, mainly in areas of the Brazilian semiarid region where the cotton is cultivated in organic system. 
Table 1. Life tables, using natural mortality data due to inviability (Inv.), desiccation (Des.), parasitism (Par.) and predation (Pred.) of the cotton boll weevil inside cotton squares on the soil in drip and sprinkler irrigated cotton. Campina Grande, Paraíba, Brazil.

\begin{tabular}{|c|c|c|c|c|c|c|c|c|c|c|}
\hline $\mathbf{X}$ & $\mathbf{L x}$ & C & Dxc & \%Dxc & $100 Q \times c$ & MSxc & Mlxc & Lxc & Log10Lxc & Kxc \\
\hline \multicolumn{11}{|c|}{ Drip irrigation } \\
\hline Egg & 585 & Inv. & 159 & 27.179 & 4.65 & 0.272 & 0.000 & 585 & 2.767 & 0.138 \\
\hline \multirow[t]{3}{*}{ Larva } & 426 & Des. & 420 & 71.795 & 16.85 & 0.986 & 0.000 & 426 & 2.629 & 1.851 \\
\hline & 0 & Par. & 1 & 0.171 & 0.04 & 0.002 & 0.000 & 6 & 0.778 & 0.079 \\
\hline & 0 & Pred. & 5 & 0.855 & 0.20 & 0.009 & 0.000 & 5 & 0.699 & 0.699 \\
\hline \multirow[t]{3}{*}{ Pupa } & 0 & Des. & 0 & 0.000 & 0.000 & 0.000 & 0.000 & 0 & 0.000 & 0.000 \\
\hline & 0 & Par. & 0 & 0.000 & 0.000 & 0.000 & 0.000 & 0 & 0.000 & 0.000 \\
\hline & 0 & Pred. & 0 & 0.000 & 0.000 & 0.000 & 0.000 & 0 & 0.000 & 0.000 \\
\hline \multirow[t]{3}{*}{ PA } & 0 & Des. & 0 & 0.000 & 0.000 & 0.000 & 0.000 & 0 & 0.000 & 0.000 \\
\hline & 0 & Par. & 0 & 0.000 & 0.000 & 0.000 & 0.000 & 0 & 0.000 & 0.000 \\
\hline & 0 & Pred. & 0 & 0.000 & 0.000 & 0.000 & 0.000 & 0 & 0.000 & 0.000 \\
\hline Adult & 0 & & & & & & & 0 & 0.000 & \\
\hline Total & & & 585 & 100.000 & & & & & & \\
\hline \multicolumn{11}{|c|}{ Sprinkler irrigation } \\
\hline Egg & 588 & Inv. & 122 & 20.748 & 20.748 & 0.207 & 1.245 & 588 & 2.768 & 0.101 \\
\hline \multirow[t]{3}{*}{ larva } & 466 & Des. & 453 & 77.041 & 97.630 & 0.972 & 5.833 & 464 & 2.667 & 1.625 \\
\hline & 0 & Par. & 0 & 0.000 & 0.000 & 0.000 & 0.000 & 11 & 1.041 & 0.000 \\
\hline & 0 & Pred. & 2 & 0.340 & 0.429 & 0.004 & 0.026 & 11 & 1.041 & 0.087 \\
\hline \multirow[t]{3}{*}{ Pupa } & 11 & Des. & 3 & 0.510 & 27.273 & 0.273 & 1.638 & 9 & 0.954 & 0.176 \\
\hline & 0 & Par. & 0 & 0.000 & 0.000 & 0.000 & 0.000 & 6 & 0.778 & 0.000 \\
\hline & 0 & Pred. & 0 & 0.000 & 0.000 & 0.000 & 0.000 & 6 & 0.778 & 0.000 \\
\hline \multirow[t]{3}{*}{ PA } & 8 & Des. & 2 & 0.340 & 25.000 & 0.250 & 1.500 & 6 & 0.778 & 0.176 \\
\hline & 0 & Par. & 0 & 0.000 & 0.000 & 0.000 & 0.000 & 4 & 0.602 & 0.000 \\
\hline & 0 & Pred. & 0 & 0.000 & 0.000 & 0.000 & 0.000 & 4 & 0.602 & 0.000 \\
\hline Adult & 6 & & & & & & & 4 & 0.602 & \\
\hline Total & & & 582 & 98.976 & & & & & & \\
\hline
\end{tabular}

$\mathrm{X}=$ stages of insect development; $\mathrm{LX}=$ number of live insects in stage $\mathrm{X} ; \mathrm{C}=$ insect mortality factor in stage $\mathrm{X}$; Dxc= number of insects dead in stage $\mathrm{X}$; $\% \mathrm{Dxc}=$ percentage of actual mortality; $(100 \mathrm{Qxc})=$ percentage of apparent mortality $(100 \mathrm{Qxc})$; MSxc= proportion of mortality; Mixc=indispensable mortality; Kxc= lethality; $\mathrm{PA}=$ pre-emergent adult.

\section{Acknowledgements}

To the Brazilian agencies "Conselho Nacional de Desenvolvimento Científico e Tecnológico (CNPq)" and "Coordenação de Aperfeiçoamento de Pessoal de Nível Superior (CAPES)" for scholarships and financial support. Grant \#047/2021, Paraiba State Research Foundation (FAPESQ). Dr. Phillip John Villani (University of Melbourne, Australia) revised and corrected the English language used in this manuscript.

\section{References}

ALLEN, K.C., LUTTRELL, R.G., SAPPINGTON, T.W., HESLER, L.S. and PAPIERNIK, S.K., 2018. Frequency and abundance of selected early-season insect pests of cotton. Journal of Integrated Pest Management, vol. 9, no. 1, pp. 20. http://dx.doi.org/10.1093/ jipm/pmy010.
AMINI, B., MADADI, H., DESNEUX, N. and LOTFALIZADEHB, H.A., 2012. Impact of irrigation systems on seasonal occurrence of Brevicoryne brassicae and its parasitism by Diaeretiella rapaeon canola. Journal of Entomological Research Society, vol. 14, no. 2, pp. 15-26.

ANDRADE, M.G., VILAS BOAS, M.A., SIQUEIRA, J.A.C., SATO, M., DIETER, J., HERMES, E. and MERCANTE, E., 2017. Uniformity microsprinkler irrigation system using statistical quality control. Ciência Rural, vol. 47, no. 4, pp. e20160546. http:// dx.doi.org/10.1590/0103-8478cr20160546.

ASSIS, G.A., ASSIS, F.A., SCALCO, M.S., PAROLIN, F.J.T., FIDELIS, I., MORAES, J.C. and GUIMARAES, R.J., 2012. Leaf miner incidence in coffee plants under different drip irrigation regimes and planting densities. Pesquisa Agropecuária Brasileira, vol. 47, no. 2, pp. 157-162. http://dx.doi.org/10.1590/S0100-204X2012000200002.

BARROS, E.M., RODRIGUES, A.R.S., BATISTA, F.C., MACHADO, A.V.A. and TORRES, J.B., 2019. Susceptibility of boll weevil to readyto-use insecticide mixtures. Arquivos do Instituto Biológico, vol. 86, p. e1232018. 
BAUDIER, K.M., MUDD, A.E., ERICKSON, S.C. and DONNELL, S.O., 2015. Microhabitat and body size effects on heat tolerance: implications for responses to climate change (army ants: Formicidae, Ecitoninae). Journal of Animal Ecology, vol. 84, no. 5, pp.1322-1330.

BÉLOT, J.L., BARROS, E.M. and MIRANDA, J.E., 2016. Riscos e oportunidades: o bicudo-do-algodoeiro. In: MINISTÉRIO DA AGRICULTURA PECUÁRIA E ABASTECIMENTO, ed. Desafios do cerrado. Cuiabá: MAPA, pp 77-118.

BEZERRA, B., BEZERRA, J.R.C., SILVA, B.B. and SANTOS, C.A.C., 2015. Surface energy exchange and evapotranspiration from cotton crop under full irrigation conditions in the Rio Grande do Norte State, Brazilian Semi-Arid. Bragantia, vol. 74, no. 1, pp. 120-128. http://dx.doi.org/10.1590/1678-4499.0245.

BEZERRA, J.R.C., AZEVEDO, P.V., SILVA, B.B. and DIAS, J.M., 2012. Evapotranspiração e coeficiente de cultivo do algodoeiro BRS200 Marron, irrigado. Revista Brasileira de Engenharia Agrícola e Ambiental, vol. 14, no. 6, pp. 625-632.

BHATTI, G.H. and PATEL, H.M., 2015. Irrigation scheduling strategies for cotton crop in semi-arid climate using weap model. Journal of Indian Water Resources Society, vol. 35, no. 1, pp. 7-15.

BUJAN, J., YANOVIAK, S.P. and KASPARI, M.E., 2016. Desiccation resistance in tropical insects: causes and mechanisms underlying variability in a Panama ant community. Ecology and Evolution, vol. 6, no. 17, pp. 6282-6291. http://dx.doi.org/10.1002/ece3.2355. PMid:27648242.

CENTRO DE ESTUDOS AVANÇADOS EM ECONOMIA APLICADA CEPEA, 2019 [viewed 29 May 2020]. Mensuração econômica da incidência de pragas e doenças no Brasil: uma aplicação para as culturas de soja, milho e algodão. Parte 1. Piracicaba: ESALQ USP. Available from: https:// www.cepea.esalq.usp.br/upload/ kceditor/files/Cepea_EstudoPragas eDoencas_Parte 1.pdf.

COELHO, R.R., SOUZA JUNIOR, J.D., FIRMINO, A.A., MACEDO, L.L., FONSECA, F.C., TERRA, W.R., ENGLER, G., ENGLER, J.A., SILVA, M.C.M. and SÁ, M.F.G., 2016. Vitellogenin knockdown strongly affects cotton boll weevil egg viability but not the number of eggs laid by females. Meta Gene, vol. 9, pp. 173-180.

DAANE, K.M. and WILLIAMS, L.E., 2003. Manipulating vineyard irrigation amounts to reduce insect pest damage. Ecological Applications, vol. 13, no. 6, pp. 1650-1666. http://dx.doi. org/10.1890/02-5328.

DAĞDELEN, N., BASAL, H., YILMAZ, E., GÜRBÜZ, T. and AKÇAY, S., 2009. Different drip irrigation regimes affect cotton yield, water use efficiency and fiber quality in western Turkey. Agricultural Water Management, vol. 96, no. 1, pp. 111-120. http://dx.doi. org/10.1016/j.agwat.2008.07.003.

FERREIRA, A.C. B., BORIN, A.L.D.C., LAMAS, F.M., BOGIANI, J.C., SILVA, M.A.S., SILVA FILHO, J.L. and STAUT, L.A., 2020. Soil carbon accumulation in cotton production systems in the Brazilian Cerrado. Acta Scientiarum. Agronomy, vol. 42, pp. e43039. http:// dx.doi.org/10.4025/actasciagron.v42i1.43039.

GHIDIU, G., KUHAR, T., PALUMBO, J. and SCHUSTER, D., 2012. Drip chemigation of insecticides as a pest management tool in vegetable production. Journal of Integrated Pest Management, vol. 3, no. 3, pp. 1-5.

GIBBS, A.G., FUKUZATO, F. and MATZKIN, L.M., 2003. Evolution of water conservation mechanisms in Drosophila. The Journal of Experimental Biology, vol. 206, no. 7, pp. 1183-1192. http:// dx.doi.org/10.1242/jeb.00233. PMid:12604578.

GREENBERG, S.M., SÉTAMOU, M., SAPPINGTON, T.W., LIU, T.-X., COLEMAN, R.J. and ARMSTRONG, J.S., 2005. Temperaturedependent development and reproduction of the boll weevil
(Coleoptera: curculionidae). Insect Science, vol. 12, no. 6, pp. 449-459. http://dx.doi.org/10.1111/j.1744-7917.2005.00057.x.

GREENBERG, S.M., SHOWLER, A.T., SAPPINGTON, T.W. and BRADFORD, J.M., 2004. Effects of burial and soil condition on postharvest mortality of boll weevils (Coleoptera: Curculionidae) in fallen cotton fruit. Journal of Economic Entomology, vol. 97, no. 2, pp. 409-413. http://dx.doi.org/10.1093/jee/97.2.409. PMid: 15154462.

HARRISON, J.F., WOODS, H.A. and ROBERTS, S.P., 2012. Ecological and environmental physiology of insects. New York: Oxford University Press. http://dx.doi.org/10.1093/acprof:o so/9780199225941.001.0001.

HILKER, M. and MEINERS, T., 2002. Induction of plant responses to oviposition and feeding by herbivorous arthropods: a comparison. Entomologia Experimentalis et Applicata, vol. 104, no. 1, pp. 181-192. http://dx.doi.org/10.1046/j.15707458.2002.01005.x.

HINDS, W.E., 1906. Proliferation as a factor in the natural control of the Mexican cotton boll weevil. Washington, D.C.: USDA Bureau of Entomology.

HINDS, W.E., 1907. An ant enemy of boll weevil. Washington, D.C.: USDA Bureau of Entomology.

INSTITUTO BRASILEIRO DE GEOGRAFIA E ESTATÍSTICA - IBGE, 2020 [viewed 10 October 2019]. Levantamento sistemático da produção agrícola [online]. Available in: https://www.sidra. ibge.gov.br/bda/agric.

INSTITUTO NACIONAL DE METEOROLOGIA - INMET, 2009 [viewed 1 September 2019]. Normais Climatológicas do Brasil, 19611990 [online]. Available in: http://www.inmet.gov.br/por-tal/ index.php?r=clima/normaisclimatologicas.

JIANG, H., TIAN, Y., YAN, W., CHEN, J., ZHANG, Z. and XU, H., 2020. Drip chemigation of flonicamid effectively controls cotton aphid (Aphis gossypii) and is benign to lady beetle (Coccinella septempunctata) and lacewing larva (Chrysoperla sinica). Crop Protection, vol. 129, pp. 105039. http://dx.doi.org/10.1016/j. cropro.2019.105039.

JIANG, H., WU, H.X., CHEN, J.J., TIAN, T.Y., ZHANG, Z.X. and XU, H.H., 2019. Sulfoxaflor applied via drip irrigation effectively controls cotton aphid (Aphis gossypii Glover). Insects, vol. 10, no. 10, pp. 345. http://dx.doi.org/10.3390/insects 10100345 . PMid:31615139.

KASPARI, M., CLAY, N.A., LUCAS, J., YANOVIAK, S.P. and KAY, A., 2015. Thermal adaptation generates a diversity of thermal limits in a rainforest ant community. Global Change Biology, vol. 21, no. 3, pp. 1092-1102. http://dx.doi.org/10.1111/gcb.12750. PMid:25242246.

KING, E.E., 1973. Endo-polymethylgalacturonase of boll weevil larvae, Anthonomus grandis: an initiator of cotton flower bud abscission. Journal of Insect Physiology, vol. 19, no. 12, pp. 2433-2437. http://dx.doi.org/10.1016/0022-1910(73)90246-1.

LOPES, C.A., MAROUELLI, W.A. and CAFÉ FILHO, A.C., 2006. Associação da irrigação com doenças de hortaliças. Revisão Anual de Patologia de Plantas, vol. 14, pp. 151-179.

MEDEIROS, M.A., SUJII, E.R. and MORAIS, H.C., 2011. Fatores de mortalidade na fase de ovo de Tuta absoluta em sistemas de produção orgânica e convencional de tomate. Bragantia, vol. 70, no. 1, pp. 72-80.

NARANJO, S.E. and ELLSWORTH, P.C., 2017. Methodology for developing life tables for sessile insects in the field using the whitefly, Bemisia tabaci, in cotton as a model system. Journal of Visualized Experiments, vol. 129, no. 129, pp. e56150. http:// dx.doi.org/10.3791/56150. PMid:29155758. 
PANTH, M., HASSLER, S.C. and BAYSAL-GUREL, F., 2020. Methods for management of soilborne diseases in crop production. Agriculture, vol. 10, no. 1, pp. 16. http://dx.doi.org/10.3390/ agriculture10010016.

PARROTT, W.L., JENKINS, J.N. and BUFORD, W.T., 1970. Instars and duration of stadia of boll weevil larvae. Annals of Entomological Society of America, vol. 63, no. 5, pp. 1265-1267.

PAULINO, J., FOLEGATTI, M.V., ZOLIN, C.A., SÁNCHEZ-ROMÁN, R.M. and JOSÉ, J.V., 2011. Situação da agricultura irrigada no Brasil de acordo com o censo agropecuário 2006. Irriga, vol. 16, no. 2, pp. 163-176.

PEREIRA, E.J.G., PICANCCO, M.C., BACCI, L., CRESPOAND, A.L.B. and GUEDES, R.N.C., 2007. Seasonal mortality factors of the coffee leafminer, Leucoptera coffeella. Bulletin of Entomological Research, vol. 97, pp. 421-432.

PIMENTA, M., MATA, R.A., VENZON, M., CUNHA, D.N.C., FONTES, E.M.G., PIRES, C.S.S. and SUJII, E.R., 2016. Survival and preference of cotton boll weevil adults for alternative food sources. Brazilian Journal of Biology = Revista Brasileira de Biologia, vol. 76, no. 2, pp. 387-395. http://dx.doi.org/10.1590/1519-6984.16214. PMid:26934148.

PIRES, C.S.S., PIMENTA, M., MATA, R.A., SOUZA, L.M., PAULA, D.P., SUJII, E.R. and FONTES, E.M.G., 2017. Survival pattern of the boll weevil during cotton fallow in Midwestern Brazil. Pesquisa Agropecuária Brasileira, vol. 52, no. 3, pp. 149-160.

PRADO, G.D., 2016. Water distribution from medium size sprinkler in solid set sprinkler systems. Revista Brasileira de Engenharia Agricola e Ambiental, vol. 20, no. 3, pp. 195-201.

RAMALHO, F.S. and SILVA, J.R.B., 1993. Período de emergência e mortalidade natural do bicudo-do-algodoeiro. Pesquisa Agropecuária Brasileira, vol. 28, no. 11, pp. 1221-1231.

RAMALHO, F.S. and WANDERLEY, P.A., 1996. Ecology and management of cotton boll weevil in South America cotton. American Entomologist, vol. 42, no. 1, pp. 41-47. http://dx.doi. $\operatorname{org} / 10.1093 / \mathrm{ae} / 42.1 .41$.

RAMALHO, F.S., GONZAGA, J.V. and SILVA, J.R.B., 1993. Método para determinação das causas de mortalidade natural do bicudo-do-algodoeiro. Pesquisa Agropecuária Brasileira, vol. 28, no. 8, pp. 877-887.

RAMALHO, F.S., SILVA, A.M.C., ZANUNCIO, J.C. and SERRÃO, J.E., 2007. Competition between Catolaccus grandis (Hymenoptera: Pteromalidae) and Bracon vulgaris (Hymenoptera: Braconidae), parasitoids of the boll weevil. Brazilian Archives of Biology and Technology, vol. 50, no. 3, pp. 371-378.

RENDON, D. and WALTON, V.M., 2019. Drip and overhead sprinkler irrigation in blueberry as cultural control for Drosophila suzukii (Diptera:Drosophilidae) in northwestern United States. Journal of Economic Entomology, vol. 112, no. 2, pp. 745-752. http:// dx.doi.org/10.1093/jee/toy395. PMid:30590521.

RIBEIRO, E.B., CASTELLANI, M.A., SILVA, C.A.D., MELO, T.L., SILVA, G.S., VALE, W.S. and SANTOS, A.S., 2015. Métodos de destruição de restos de cultura do algodoeiro e sobrevivência do bicudo. Pesquisa Agropecuária Brasileira, vol. 50, no. 11, pp. 993-998. http://dx.doi.org/10.1590/S0100-204X2015001100001.

RIBEIRO, P.A., SUJII, E.R., DINIZ, I.R., MEDEIROS, M.A., SALGADOLABORIAU, M.L., BRANCO, M.C., PIRES, C.S.S. and FONTES, E.M.G., 2010. Alternative food sources and overwintering feeding behavior of the boll weevil, Anthonomus grandis Boheman
(Coleoptera: Curculionidae) under the tropical conditions of Central Brazil. Neotropical Entomology, vol. 39, no. 1, pp. 28-34.

RUNIA, W.T., MOLENDIJK, L.P.G., VAN DEN BERG, W., STEVENS, L.H., SCHILDER, M.T. and POSTMA, J. 2014. Inundation as tool for management of Globodera pallida and Verticillium dahliae. Acta Horticulturae, vol. 1044, pp. 195-201.

SANTOS, R.L., NEVES, R.C.S., COLARES, F. and TORRES, J.B., 2013. Parasitoides do bicudo Anthonomus grandis e predadores residentes em algodoeiro pulverizado com caulim. Semina, vol. 34, no. 6, pp. 3463-3474.

SHOWLER, A.T., 2007. Subtropical boll weevil ecology. American Entomologist, vol. 53, no. 4, pp. 240-249. http://dx.doi. org/10.1093/ae/53.4.240.

SILVA, A.L.A.L. and SILVA, C.A.D., 2015. Concentração eficiente e econômica de caulim para a proteção de algodoeiro contra o bicudo. Pesquisa Agropecuária Brasileira, vol. 50, no. 9, pp. 763-768.

SILVA, C.A.D. and RAMALHO, F.S., 2013. Kaolin spraying protects cotton plants against damages by boll weevil Anthonomus grandis Boheman (Coleoptera: curculionidae). Journal of Pest Science, vol. 86, no. 3, pp. 563-569. http://dx.doi.org/10.1007/ s10340-013-0483-0.

SILVA, C.A.D., DUARTE, M.M.F., GONÇALVES, S.G. and VASCONCELOS, E.D., 2017. Spatial and temporal distribution of cotton squares and small cotton bolls fallen on ground after damage by boll weevil and the efficiency of the equipment used to collect them. Ciência Rural, vol. 47, no. 7, p. e20160653.

SILVA, C.A.D., RAMALHO, F.S., MIRANDA, J.E., ALMEIDA, R.P., RODRIGUES, S.M.M. and ALBUQUERQUE, F.A., 2013. Sugestões técnicas para o manejo integrado de pragas do algodoeiro no Brasil. Campina Grande: Embrapa/CNPA, 12 p.

SILVA, C.S.B., PRICE, B.E. and WALTON, V.M., 2019. Water-deprived parasitic wasps (Pachycrepoideus vindemmiae) kill more pupae of a pest (Drosophila suzukii) as a water-intake strategy. Scientific Reports, vol. 9, no. 1, pp. 3592. http://dx.doi.org/10.1038/s41598019-40256-8. PMid:30837618.

SILVA, R.A., DEGRANDE, P.E., GOMES, C.E.C., SOUZA, E.P. and LEAL, M.F., 2018. Phytophagous insects in cotton crop residues during the fallow period in the state of Mato Grosso do Sul, Brazil. Pesquisa Agropecuária Brasileira, vol. 53, no. 8, pp. 875-884.

SOUTHWOOD, T.R.E. and HENDERSON, P.A., 2000. Ecological methods. London: Blackwell Science.

VARLEY, G.C. and GRADWELL, G.R., 1968. Populations models for the winten moth. In: T.R.E. SOUTHWOOD, ed. Insect abundance. London: The Royal Etomological Sciety, pp. 50-60.

ZONTA, J.H., BEZERRA, J.R.C., SOFIATTI, V. and BRANDÃO, Z.N., 2015. Yield of cotton cultivars under different irrigation depths in the Brazilian semi-arid region. Revista Brasileira de Engenharia Agrícola e Ambiental, vol. 19, no. 8, pp. 748-754. http://dx.doi. org/10.1590/1807-1929/agriambi.v19n8p748-754.

ZULFIQAR, F., DATTA, A. and THAPA, G.B., 2017. Determinants and resource use efficiency of "better cotton": an innovative cleaner production alternative. Journal of Cleaner Production, vol. 166, pp. 1372-1380. http://dx.doi.org/10.1016/j.jclepro.2017.08.155. 